\title{
Quinonoid and phenazine compounds: synthesis of new antimycobacterial prototypes
}

\author{
Paula F. Carneiro, ${ }^{a}$ Maria do Carmo F.R. Pinto, ${ }^{a}$ Tatiane S. Coelho, ${ }^{b}$ Antonio V. \\ Pinto, ${ }^{a \dagger}$ Kelly C.G. Moura, ${ }^{a}$ Pedro A. da Silva ${ }^{b}$ and Eufrânio N. da Silva Júnior ${ }^{\mathrm{c} *}$ \\ ${ }^{a}$ Núcleo de Pesquisas em Produtos Naturais, UFRJ, RJ, Brazil; ${ }^{b}$ Laboratório de Micobacterias,
} Departamento de Patologia, FURG, RS, Brazil; ' Laboratório de Química Sintética e Heterocíclica, Instituto de Ciências Exatas, Departamento de Química, UFMG, MG, Brazil.

*eufranio@ufmg.br

Keywords: quinone, tuberculosis and lapachol

\section{INTRODUCTION}

Tuberculosis (TB) is a very aggressive disease caused by Mycobacterium tuberculosis (MT) and still represents nowadays a cause of globally death. ${ }^{1}$

Recently, our research group has investigated the antitumor, ${ }^{2}$ trypanocidal ${ }^{3}$ and antimycobacterial ${ }^{4}$ activity of a large number of compounds obtained from lapachol (1). In this context, we present the synthesis and evaluation of phenazine compounds obtained from diverse quinones against MT pansusceptible and resistant strains.

\section{RESULTS AND DISCUSSION}

Initially, from lapachol (1) the phenazine 2 was prepared. Lapachol (1) was reduced by catalytic reduction and the substances $\mathbf{3}$ and $\mathbf{4}$ were prepared and used to synthesize the phenazines 5 and 7 in good yields and the ether derivatives 6 and 8, respectively. Finally, the ether phenazine derivatives 9 and $\mathbf{1 0}$ were obtained from the substances $\mathbf{6}$ and $\mathbf{8}$, as yellow solids (Scheme 1).

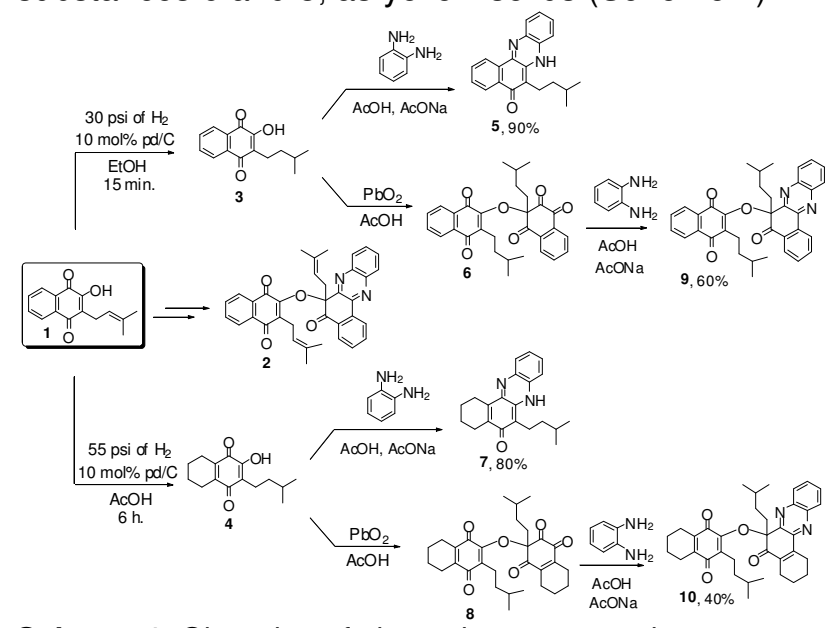

Scheme 1. Obtention of phenazine compounds.

The minimum inhibitory concentrations (MICs) for the compounds were evaluated against MT $\mathrm{H}_{37} \mathrm{Rv}$, MT rifampicin resistance (ATCC 35338) and MT isoniazid resistance (ATCC 35822). The toxicity of compounds toward a normal proliferating cell was investigated using the Alamar Blue assay. The compounds were classified by us according to their activity against MT as highly active (MIC $\leq 3 \mu \mathrm{g} / \mathrm{mL}$ ), lowly active $(3 \mu \mathrm{g} / \mathrm{mL}<\mathrm{MIC}<100 \mu \mathrm{g} / \mathrm{mL}$ and), or inactive (MIC > $100 \mu \mathrm{g} / \mathrm{mL})$.

Lapachol (1) and the compounds 2, 9 and 10, were considered inactive when MIC $>100 \mu \mathrm{g} / \mathrm{mL}$ for $\mathrm{H}_{37} \mathrm{Rv}$, ATCC 35338 and ATCC 35822 strains and the substances $\mathbf{3}$ and $\mathbf{4}$ were lowly active.

With MIC value of $25,12.5$ and $25 \mu \mathrm{g} / \mathrm{mL}$ for MT $\mathrm{H}_{37} \mathrm{Rv}$, MT rifampicin resistance and MT isoniazid resistance the reduced quinone 4 can be considered as an important prototype.

The substance 7 was highly active [MIC $\leq 3$ $\mu \mathrm{g} / \mathrm{mL}(9.75 \mu \mathrm{M})]$ against $\mathrm{MT} \mathrm{H}_{37} \mathrm{Rv}$. For ATCC 35822 strains the compound was less active with MIC value of $12.5 \mu \mathrm{g} / \mathrm{mL}$ and for ATCC 35822 strain was inactive. The substance 7 was not cytotoxic against normal cells $\left(\mathrm{IC}_{50}>25 \mu \mathrm{g} / \mathrm{mL}\right)$.

\section{CONCLUSION}

All the new compounds were synthesized in good yields, by the proposed methodology. The substance 7 was highly active [MIC $\leq 3 \mu \mathrm{g} / \mathrm{mL}(9.75$ $\mu M)$ ] against MT $\mathrm{H}_{37} \mathrm{Rv}$ and emerge as interesting new lead compound in drug development for the treatment of TB.

\section{ACKNOWLEDGEMENTS}

This research was supported by grants from the CNPq, FAPERJ, CAPES, UFRJ, FURG and UFMG.

\section{REFERENCES}

Fears, R.; Kaufmann, S.; Meulen, V.; Zumla, A. Tuberculosis 2010, 90, 182.

${ }^{2}$ da Silva Júnior, E. N.; de Souza, M. C. B. V.; Pinto, A. V.; Pinto, M. C. F. R.; Goulart, M. O. F.; Barros, F. W. A.; Pessoa, C.; Costa-Lotufo, L. V.; Montenegro, R. C.; de Moraes, M. O.; Ferreira, V. F. Bioorg. Med. Chem. 2007, 15, 7035

${ }^{3}$ da Silva Júnior, E. N.; Menna-Barreto, R. F. S.; Pinto, M. C. F. R.; Silva, R. S. F.; Teixeira, D. V.; de Souza, M. C. B. V.; de Simone, C. A.; de Castro, S. L.; Ferreira, V. F.; Pinto, A. V. Eur. J. Med. Chem. 2008, 43, 1774

${ }^{4}$ Coelho T. A.; Silva, R. S. F.; Pinto, A. V.; Pinto, M. C. F. R. Scaini, C. J.; Moura, K. C. G.; da Silva, P. A. Tuberculosis 2010, 90, 293. 